\title{
Improving Activity and Learning Mathematics Through Strategies Teams Games Tournaments for Students Of Class IV SDN Sambirejo 4
}

\section{Ari Tejo Laksono}

SD Negeri Sambirejo 4

aritejolaksono755@gmail.com

\section{Article History}

received 3/12/2020

\begin{abstract}
This study aims to improve mathematics learning outcomes about the concept of integer arithmetic operations in fourth grade students of SD Negeri Sambirejo 4 Sambirejo District for the 2019/2020 academic year. This study uses a Classroom Action Research (CAR) model which is carried out in 2 cycles. The results showed that there was an increase in student activity and learning outcomes using the Teams Group Tournament strategy. In the pre-cycle stage of 24 students who achieved learning completeness 10 students (41.7\%). Then in the first cycle of learning completeness reached 16 students (66.7\%) and in the second cycle there was an increase to 18 students (75\%). So the conclusion of this study shows that learning with the Teams Group Tournament strategy improves mathematics learning outcomes for fourth grade students at SD Negeri Sambirejo 4, Sambirejo District, 2019/2020 Academic Year.
\end{abstract}

Keywords: Teams Group Tournament learning strategy

\section{Abstrak}

Penelitian ini bertujuan untuk meningkatkan hasil belajar matematika tentang konsep operasi hitung bilangan bulat pada siswa kelas IV SD Negeri Sambirejo 4 Kecamatan Sambirejo Tahun Pelajaran 2019/2020. Penelitian ini menggunakan model Penelitian Tindakan Kelas (PTK) yang dilaksanakan dalam 2 siklus. Hasil penelitian menunjukkan bahwa terdapat peningkatan keaktifan dan hasil belajar siswa dengan menggunakan strategi Teams Group Tournament. Pada tahap pra siklus dari 24 siswa yang mencapai ketuntasan belajar 10 siswa $(41,7 \%)$. Kemudian pada siklus 1 ketuntasan belajar mencapai 16 siswa $(66,7 \%)$ dan pada siklus 2 terjadi peningkatan menjadi 18 siswa (75\%). Sehingga kesimpulan penelitian ini menunjukkan pembelajaran dengan strategi Teams Group Tournament meningkatkan hasil belajar matematika pada siswa kelas IV SD Negeri Sambirejo 4 Kecamatan Sambirejo Tahun Pelajaran 2019/2020.

Kata kunci: strategi pembelajaran Teams Group Tournament

Social, Humanities, and Education Studies (SHEs): Conference Series https://jurnal.uns.ac.id/shes 


\section{PENDAHULUAN}

Kemajuan ilmu pengetahuan dan teknologi menuntut pengembangan kemampuan siswa sekolah dasar dalam bidang ilmu pengetahuan, diantaranya adalah mata pelajaran matematika, yang sangat dibutuhkan untuk melanjutkan belajar ke jenjang yang lebih tinggi, mengembangkan bakat dan minat serta kesiapan dalam hidup bermasyarakat.

Melatih keterampilan siswa untuk berpikir secara kreatif dan inovatif melalui matematika merupakan pelatihan awal bagi siswa untuk berpikir kritis dalam mengembangkan bakat dan minat siswa. Sehubungan dengan hal tersebut, pengajaran mata pelajaran matematika mendapat perhatian besar untuk seluruh jenjang satuan pendidikan, apalagi jenjang sekolah dasar. Keberhasilan pembelajaran sangat bergantung pada kompetensi guru dan siswa. Pembelajaran akan lebih bermakna apabila menggunakan media dan metode untuk mencapai tujuan.

Tidak dapat dipungkiri bahwa yang menentukan sikap, mental, perilaku, kepribadian dan kecerdasan anak adalah pendidikan, pengalaman dan latihan-latihan yang diberikan dan dialami serta dilalui mereka sejak kecil. sebuah kalimat yang dikemukakan oleh Carla Rinaldi dalam 30 Kiat Mencetak Anak Kreatif Mandiri (2006: 5), "Kesuksesan dalam pendidikan anak sejak dini bergantung pada apakah pendidikan itu dapat berhubungan dengan lingkungan belajar di rumah dan di sekolah. Hal itu di dasarkan pada interaksi dan komunikasi antara anak, guru dan anak tua".

Pendidikan bertujuan untuk menumbuhkembangkan potensi yang dimiliki siswa untuk bekal dalam menghadapi tantangan di masa akan datang. Pendidikan akan membawa perubahan sikap, perilaku, dan nilai-nilai pada individu, kelompok dan masyarakat. Melalui pendidikan diharapkan mampu membentuk individu-individu yang berkompetensi di bidangnya sehingga sejalan dengan perkembangan ilmu pengetahuan dan teknologi (Rubiyanto, 2004: 1).

Salah satu strategi pembelajaran yang dapat mengajak siswa untuk terlibat langsung dalam proses belajar mengajar adalah strategi pembelajaran cooperative learning tipe teams games tournaments (TGT) Dalam strategi pembelajaran ini siswa diberi tanggung jawab untuk menyelesaikan suatu tugas secara kelompok, adapun langkah-langkahnya adalah : siswa dibagi menjadi beberapa kelompok yang beranggotakan 3 sampai 5 anak, masing-masing kelompok diberi tugas untuk dipecahkan bersama, penilaian akhir ditentukan oleh keberhasilan kelompok, sehingga setiap anggota kelompok mempunyai tanggungjawab penuh terhadap kelompoknya.

Berdasarkan observasi awal, pada pembelajaran matematika konsep operasi hitung bilangan bulat, diperoleh beberapa fakta dilapangan tentang hasil belajar siswa yang masih rendah. Kesulitan yang sering dihadapi siswa adalah pada operasi hitung bilangan bulat dengan operasi hitung campuran. Adapun data hasil observasi pada ulangan matematika konsep operasi hitung bilangan bulat dengan KKM 68 sebagai berikut : pada ulangan harian matematika, dari 24 siswa kelas IV SDN Sambirejo 4, (1) siswa yang mendapat nilai 90 ada 2 siswa (8,3\%). (2) siswa yang mendapat nilai 80 sebanyak 3 siswa (12,5\%). (3) siswa yang mendapat nilai 70 sebanyak 6 siswa (25 $\%)$, siswa yang mendapat nilai 60 sebanyak 4 siswa (16,7 \%), dan siswa yang mendapat nilai dibawah 60 sebanyak 9 siswa (37,5\%) yang terdiri dari 5 siswa mendapat nilai 50 dan 4 siswa dengan nilai 40 . Nilai rata-rata yang dicapai kelas tersebut sebesar 62,1 , berarti nilai rata-rata yang dicapai masih dibawah KKM yang di tetapkan sebesar 70 .

Bertolak dari fakta inilah, maka peneliti tertarik untuk mengadakan penelitian tindakan kelas dengan judul "Upaya Meningkatkan Hasil Belajar Matematika Pada Konsep Operasi Hitung Bilangan Bulat Melalui Strategi Pembelajaran Tipe teams games tournaments Bagi Siswa Kelas IV Semester II SDN Sambirejo 4 Tahun 2019/2020". 


\section{METODE}

Berdasarkan latar belakang permasalahan yang ada maka jenis penelitian yang digunakan adalah penelitian tindakan kelas dengan menggunakan 2 siklus yang masing-masing siklus terdiri dari kegiatan perencanaan, pelaksanaan, pengamatan, penilaian. Metode yang digunakan untuk penelitian ini yaitu strategi pembelajaran cooperative learning tipe teams games tournaments (TGT) untuk dapat meningkatan hasil belajar matematika pada peserta didik kelas IV Semester II SD Negeri Sambirejo 4 Tahun Pelajaran 2019/2020, Kecamatan Sambirejo Kabupaten Sragen". Subjek dalam penelitian Penelitian Tindakan Kelas ini yaitu peserta didik kelas IV tahun ajaran 2019/2020 dengan jumlah sebanyak 24 peserta didik. Tempat Penelitian Tindakan Kelas ini dilaksanakan di ruang kelas IV SD Negeri Sambirejo 4. Waktu penelitian berlangsung dari 18 Januari 2020 sampai dengan 1 Februari 2020.Teknik yang digunakan untuk mengumpulkan data adalah teknik tes dan non tes. Analisis data dalam penelitian ini dilakukan dengan menggunakan metode alur. Menurut Miles dan Huberman dalam Sutama (2002:104), langkah-langkah yang harus dilalui dalam metode alur meliputi reduksi data, penyajian data, dan penarikan kesimpulan

\section{HASIL DAN PEMBAHASAN \\ 1. Peningkatan keaktifan siswa dalam pembelajaran matematika melalui penerapan strategi pembelajaran teams-games-tournaments}

Pada observasi awal, sebelum menggunakan strategi pembelajaran cooperative learning tipe teams games tournaments, keaktifan siswa yang nampak pada kegiatan pembelajaran sebagai berikut: siswa yang bertanya kepada guru sebanyak 2 anak (8,3\%), siswa yang berdiskusi dalam kelompok ada 4 anak $(16,7 \%)$, siswa yang menjawab pertanyaan guru sebanyak 3 anak $(12,5 \%)$, siswa yang mengerjakan soal di depan kelas sebanyak 3 anak (12,5\%), dan siswa yang selesai dalam mengerjakan tugas mandiri sebanyak 6 anak (25\%).

Data yang diperoleh pada siklus I menggunakan strategi pembelajaran cooperative learning tipe teams games tournaments, mengenai aktivitas siswa sebagai berikut: siswa yang bertanya pada guru atau siswa lain sebanyak 6 anak (25\%), siswa yang berinteraksi dalam kelompok ada 8 anak (33,3\%), siswa yang menjawab pertanyaan guru sebanyak 7 anak $(29,2 \%)$, siswa yang mengerjakan tugas di depan kelas sebanyak 8 anak $(33,4 \%)$, hal ini menunjukkan adanya peningkatan keaktifan siswa dalam kegiatan pembelajaran.

Data yang diperoleh pada siklus II mengenai aktivitas siswa sebagai berikut: siswa yang berani bertanya pada guru sebanyak 8 anak $(33,4 \%)$, siswa yang berinteraksi dalam kelompok ada 12 anak (50\%), siswa yang menjawab pertanyaan atau memberikan pendapatnya tanpa ditunjuk sebanyak 12 anak (50\%), siswa yang mengerjakan tugas di depan kelas sebanyak 10 anak (41,7\%), hal ini menunjukkan adanya peningkatan keaktifan siswa dalam kegiatan pembelajaran.

Tabel 1. Data Peningkatan Keaktifan Siswa

\begin{tabular}{lllll}
\hline No & Indikator keaktifan & Pra siklus & Siklus I & Siklus II \\
\hline 1 & $\begin{array}{l}\text { Bertanya kepada guru } \\
\text { atau siswa lain }\end{array}$ & $2(8,3 \%)$ & $6(25 \%)$ & $8(33,4 \%)$ \\
2 & $\begin{array}{l}\text { Berinteraksi dalam } \\
\text { kelompok }\end{array}$ & $4(16,7 \%)$ & $8(33,3 \%)$ & $12(50 \%)$ \\
3 & $\begin{array}{l}\text { Menjawab atau } \\
\text { memberikan pendapat }\end{array}$ & $3(12,5 \%)$ & $7(29,2 \%)$ & $12(50 \%)$ \\
4 & $\begin{array}{l}\text { Mengerjakan tugas di } \\
\text { depan kelas }\end{array}$ & $3(12,5 \%)$ & $8(33,3 \%)$ & $10(41,7 \%)$ \\
\hline
\end{tabular}




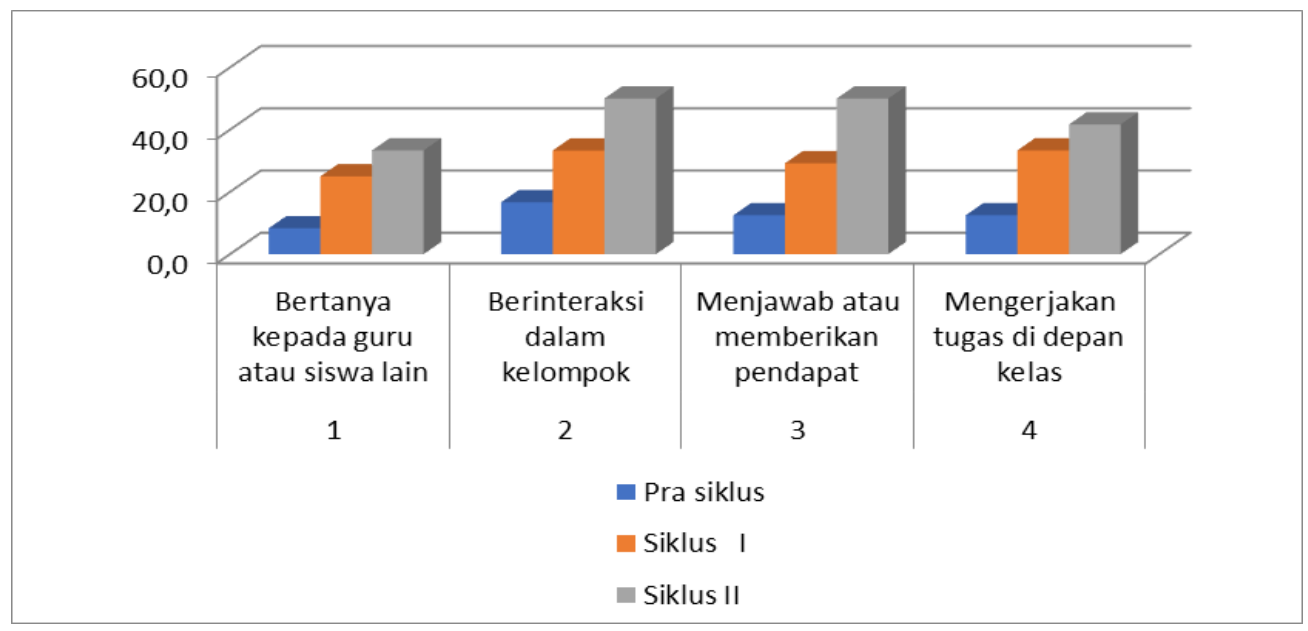

\section{Gambar 1. Grafik Peningkatan Keaktifan Siswa}

Gambar 1. Menunjukkan dengan menerapkan strategi pembelajaran cooperative learning tipe teams-games-tournaments ini telah meningkatkan keaktifan belajar peserta didik yang meliputi 4 indikator keaktifan.

Peningkatan keaktifan peserta didik menjelaskan perubahan perilaku peserta didik sebelum perbaikan/prasiklus dan setelah diadakan perbaikan pembelajaran pada siklus I dan II. Peningkatan keaktifan peserta didik akan terlihat pada perubahan perilaku. Peningkatan keaktifan peserta didik dapat dibuktikan dari hasil evaluasi non tes yaitu observasi dan dokumentasi, hasil observasi digunakan untuk mengetahui perubahan perilaku peserta didik selama pembelajaran matematika. Berdasarkan pernyataan diatas menunjukan bahwa terjadi peningkatan perubahan perilaku peserta didik selama pembelajaran. Hal ini bisa dilihat dari hasil observasi di atas yang mengalami peningkatan dari siklus I ke siklus II. Indikator pertama mengenai bertanya kepada guru atau siswa lain, hasil observasi menunjukkan kenaikan dari siklus I ke siklus II yaitu $25 \%$ naik ke $33,4 \%$ dengan peningkatan sebesar $8,4 \%$. Indikator kedua mengenai berinteraksi dalam kelompok peserta didik, hasil observasi menunjukkan dari siklus I ke Siklus II yaitu 33,3\% naik ke 50\% peningkatan sebesar 16,7\%. Indikator ketiga mengenai menjawab atau memberikan pendapat, hasil observasi menunjukan kenaikan dari siklus I ke Siklus II yaitu $29,2 \%$ naik ke $50 \%$ peningkatan sebesar 20,8\%. Indikator keempat mengenai mengerjakan tugas di depan kelas, hasil obserasi menunjukan kenaikan dari siklus I ke siklus II yaitu $33,3 \%$ naik ke $41,7 \%$ meningkat sebesar $8,4 \%$. Hal ini membuktikan bahwa ada peningkatan keaktifan siswa setelah penerapan strategi teams games tournaments dalam kegiatan pembelajaran.

2. Peningkatan hasil belajar siswa dalam pembelajaran matematika melalui penerapan strategi pembelajaran teams-games-tournaments

Pada observasi awal, peneliti memperoleh data tentang hasil belajar siswa sebagai berikut : jumlah siswa yang mendapat nilai 40 sebanyak 4 siswa, siswa yang mendapat nilai 50 sebanyak 5 siswa, siswa yang mendapat nilai 60 sebanyak 4 siswa, siswa yang mendapat nilai 70 sebanyak 6 siswa, siswa yang mendapat nilai 80 sebanyak 3 siswa. dan siswa yang mendapat nilai 90 sebanyak 2 siswa.

Setelah pembahasan hasil diskusi pada siklus I selesai, guru memberikan soal tugas mandiri kepada siswa untuk dikerjakan secara individu dengan indikator operasi hitung pengurangan bilangan pecahan. Pada siklus I diperoleh data hasil belajar siswa sebagai berikut: siswa yang mendapat nilai 50 sebanyak 
2 siswa, siswa yang mendapat nilai 60 sebanyak 6 siswa, siswa yang mendapat nilai 70 sebanyak 10 siswa, siswa yang mendapat nilai 80 sebanyak 4 siswa, dan siswa yang mendapat nilai 90 sebanyak 2 siswa.

Pada siklus II diperoleh data hasil belajar siswa sebagai berikut: siswa yang mendapat nilai 60 sebanyak 6 siswa, siswa yang mendapat nilai 70 sebanyak 9 siswa, siswa yang mendapat nilai 80 sebanyak 7 siswa, siswa yang mendapat nilai 90 sebanyak 1 siswa, siswa yang mendapat nilai 100 sebanyak 1 siswa.

Tabel 2. Data Peningkatan Hasil belajar Siswa

\begin{tabular}{llccc}
\hline No & \multicolumn{1}{c}{ Aspek } & Prasiklus & Siklus I & Siklus II \\
\hline \multirow{2}{*}{ 1. } & Siswa yang belum & 14 & 8 & 6 \\
& mencapai KKM & $(58,3 \%)$ & $(33,3 \%)$ & $(25 \%)$ \\
2. & Siswa yang memperoleh & 10 & 16 & 18 \\
& nilai di atas KKM & $(41,7 \%)$ & $(66,7 \%)$ & $(75 \%)$ \\
\hline
\end{tabular}

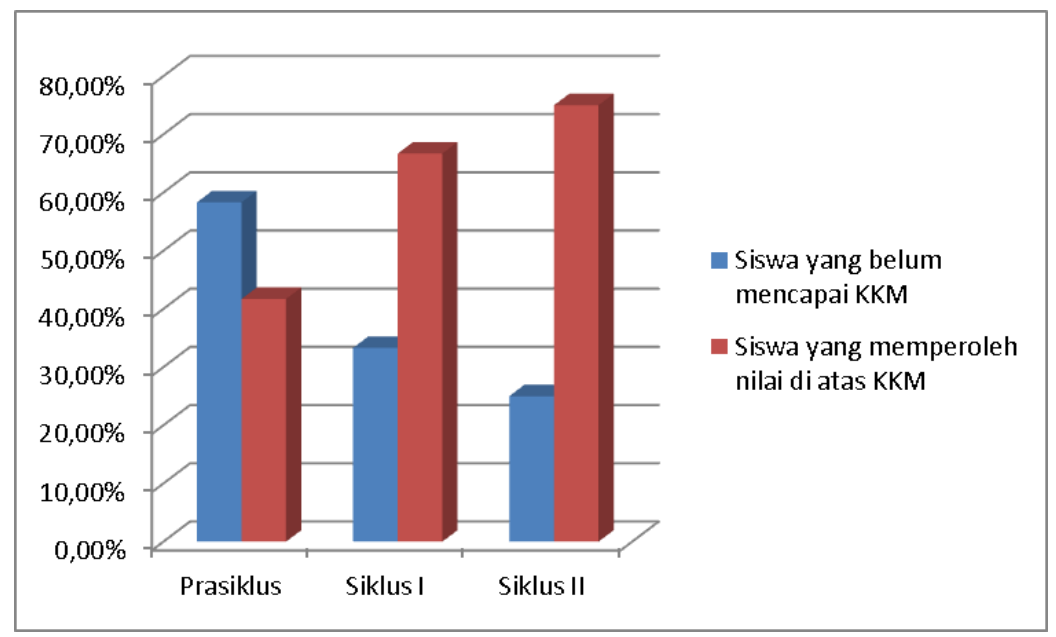

Gambar 2. Grafik Peningkatan Hasil belajar Siswa

Gambar 2. Menunjukan bahwa siswa yang belum mencapai KKM sebelum tindakan adalah 14 siswa (58,3\%), pada siklus I adalah 8 siswa $(33,3 \%)$, dan pada siklus II adalah 6 siswa (25\%). Sedangkan jumlah siswa yang memperoleh nilai di atas KKM adalah sebelum tindakan 10 siswa $(41,7 \%)$ pada siklus I adalah 16 siswa (66,7\%) pada siklus II adalah 18 siswa (75\%). Hal ini membuktikan bahwa ada peningkatan hasil belajar siswa pada mata pelajaran matematika setelah melalui penerapan strategi pembelajaran teams games tournaments.

\section{SIMPULAN}

Hasil penelitian tindakan kelas dapat disimpulkan: 1). Peningkatan keaktifan siswa melalui strategi pembelajaran TGT meliputi: a). Keaktifan siswa dalam bertanya mengalami peningkatan. pra siklus ada 2 siswa, siklus I sebanyak 6 siswa pada siklus II meningkat menjadi 8 siswa. b).Peningkatan keaktifan siswa dalam menjawab pertanyaan guru. Pada pra siklus ada 3 siswa, pada siklus I ada 12 siswa, pada siklus II ada 12 siswa. c).Peningkatan keaktifan siswa dalam berinteraksi selama diskusi yaitu 4 siswa pada prasiklus, 12 siswa pada siklus I, dan 12 siswa pada siklus II. d). Keaktifan siswa dalam mengerjakan soal atau tugas di depan kelas mengalami 
peningkatan yaitu 3 siswa pada prasiklus, 8 siswa pada siklus I, dan 10 siswa pada siklus II. 2). Hasil belajar yang dicapai siswa mengalami peningkatan. Hal ini dilihat dari ketuntasan belajar siswa yaitu 10 siswa pada pra siklus, 16 siswa pada siklus I, dan 18 siswa pada siklus II. Tindak mengajar yang telah dilakukan guru dan tindak belajar yang dilakukan siswa memberi gambaran sejauhmana keaktifan siswa dapat meningkat. Strategi pembelajaran TGT yang diterapkan menjadi pemicu siswa untuk aktif dan melibatkan diri dalam kegiatan pembelajaran. Hal ini memberi implikasi bahwa peningkatan keaktifan dan keterlibatan siswa akan berpenaruh pada peningkatan keaktifan dan hasil belajar.

\section{DAFTAR PUSTAKA}

Sagala, Syaiful. 2003. Konsep dan Makna Pembelajaran. Bandung: Alfabeta Surya, M. 2003. Perkembangan Peserta Didik. Jakarta : Universitas Terbuka Karso. 2004. Pendidikan Matematika. Jakarta: Pusat Penerbitan Universitas Terbuka Slavin,R.E. 2005. Cooperative Learning: theory, research and practice (N.Yusron Terjemahan). London: Allymand Bacon

Karim. MA. 2007. Pendidikan Matematika II. Jakarta: Pusat Penerbitan Universitas Terbuka

Isjoni. 2007. Cooperative Learning: Efektivitas Pembelajaran Kelompok. Bandung: Alfabeta.

Lie, A. 2008. Cooperative Learning: Mempraktikan Cooperative Learning di Ruangruang Kelas. Jakarta: Grasindo.

Sanjaya, Wina. 2008. Strategi Pembelajaran Berorientasi Standar Proses Pendidikan. Jakarta: Kencana Prenada Media Group

Ade, S. 2011. Model-model Pembelajaran. Jakarta: Bumi Aksara.

Djamarah, Syaiful B. 2018. Strategi Belajar Mengajar. Jakarta: Rineka Cipta..

Sri Anitah, W. 2019. Strategi Pembelajaran di SD. Tangerang Selatan. Gramedia.

Doantara Yasa: http://ipotes.wordpress.com/2008/05/11/pembelajaran-kooperatif-tipeteams-games-tournaments-tgt/ 